Publicação organizada pelo Programa de

Mestrado Profissional Stricto Sensu em

Engenharia Civil da Universidade São Judas

Volume 03 - Edição 03

Janeiro - Dezembro de 2020

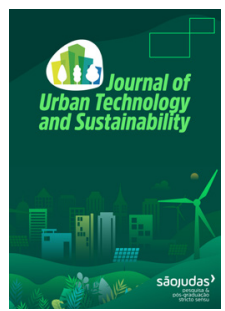

\author{
Characterization of construction and demolition wastes for civil engineering uses \\ João A. Paschoalin Filhoa,", Diego G. Camelob, David de Carvalhoc, António J. G. Dias ${ }^{d}$, Brenno A. M. Versolatto ${ }^{b}$ \\ ${ }^{a}$ Nove de Julho University- Master Degree in Sustainable and Intelligent Cities, Itaci Street, 206, apt 83, São Paulo/Brazil, 02460-030. \\ ${ }^{b}$ Nove de Julho University - Master Degree in Sustainable and Intelligent Cities, São Paulo/Brazil.

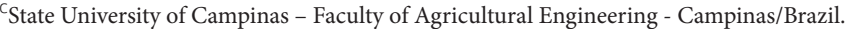 \\ ${ }^{d}$ University of Porto, Portugal - Faculty of Sciences. Department of Geology and Territory - Porto/Portugal.
}

\section{Article info}

Received 14 April 2020

Received in revised form 29

May 2020

Accepted 03 June 2020

\section{Keywords}

Civil construction

Construction and demolition

waste

Recycling

\section{Abstract}

Construction and demolition wastes have been studied by technical means to develop management tools to reduce environmental impacts. Among the methods evaluated, recycling can be highlighted. This article demonstrates the characterization of engineering parameters for concrete construction wastes obtained at a C\&DW recycling plant near São Paulo. To this end, laboratory tests were performed according to relevant technical standards to determine the following characteristics: specific weight, integrity using ultrasound, compressive strength, elasticity modulus, and absorption. The parameters obtained may serve to characterize the waste under study, as well as initial values for the development of basic civil engineering projects with low structural responsibility.

\title{
Caracterização de resíduos de construção e demolição para uso em engenharia civil
}

\section{Informações}

Recebido 14 Abril 2020

Manuscrito revisado recebido 29 Maio 2020

Aceito 3 Junho 2020

\section{Palavras-chave}

Construção civil

Resíduos de construção e

demolição

Reciclagem

\section{Resumo}

Resíduos de construção e demolição têm sido estudados por meios técnicos para desenvolver ferramentas de gestão para reduzir os impactos ambientais. Dentre essas, a reciclagem pode ser destacada. Este artigo demonstra a obtenção e avaliação de parâmetros de engenharia para resíduos de construção de concreto obtidos em uma usina de reciclagem de RCD próxima a São Paulo. Para tanto, foram realizados ensaios laboratoriais de acordo com as normas técnicas pertinentes para determinação das seguintes características: peso específico, integridade por ultrassom, resistência à compressão, módulo de elasticidade e absorção. Os parâmetros obtidos podem servir para melhor caracterizar os resíduos em estudo, bem como valores iniciais para o desenvolvimento de projetos básicos de engenharia civil com baixa responsabilidade estrutural.

\section{Caracterización de residuos de construcción y demolición para su uso en ingeniería civil}

\section{Información}

Recibido 14 Abril 2020

Manuscrito revisado recibido 29 Mayo 2020

Aceptado 3 Junio 2020

\section{Palabras clave}

Construcción Civil

Resíduos de construcción y demolición

Reciclaje

\section{Resumen}

Residuos de construcción y demolición han sido estudiados por medios técnicos para desarrollar herramientas de gestión que reduzcan los impactos ambientales. Entre estas, se puede destacar el reciclaje. También es de destacar que el entorno técnico aún no cuenta con una cantidad adecuada de trabajos científicos que presenten el estudio de las características de ingeniería obtenidas para los residuos de la construcción, lo que, muchas veces, imposibilita considerar estos residuos para su uso en ingeniería civil. Así, este artículo demuestra la obtención y evaluación de parámetros de ingeniería para residuos de construcción de hormigón obtenidos en una planta de reciclaje de RCD cerca de São Paulo. Para ello, se realizaron pruebas de laboratorio de acuerdo con las normas técnicas relevantes para determinar las siguientes características: peso específico, integridad mediante ultrasonidos, resistencia a la compresión, módulo de elasticidad y absorción. Los parámetros obtenidos pueden servir para caracterizar mejor el residuo en estudio, así como valores iniciales para el desarrollo de proyectos de ingeniería civil básica con baja responsabilidad estructural.

\footnotetext{
* Corresponding author at: Nove de Julho University- Master Degree in Sustainable and Intelligent Cities, São Paulo/Brazil.

E-mail address: paschoalinfilho@yahoo.com (João A. Paschoalin Filho)
} 


\section{Introduction}

Civil construction consists of an essential industrial sector, responsible for a country's social and economic development, generating direct and indirect jobs. According to Maia and Neto (2016), the construction industry has generated about 7\% of all world jobs in 2015 and reduced housing and infrastructure deficits. According to the Brazilian Institute of Geography and Statistics (IBGE), the civil construction production chain has represented $5.2 \%$ of Brazilian Gross Domestic Product (GDP) in 2016 (IBGE, 2017).

However, despite proportioned benefits, the civil construction sector is responsible for environmental impacts caused by its daily activities, such as noise, air pollution, dust, solid waste generation, natural resources impoverishment (YUAN, 2012; CHEN et al., 2019). According to Esa et al. (2017), 40\% of industrial waste generated in the world comes from the construction industry.

According to Jin et al. (2019), construction and demolition waste management is an interdisciplinary issue that involves environmental, technical, economic, and social aspects. It also covers complicated issues from political, management, and engineering perspectives.

Construction and demolition waste (C\&DW) recycling bring environmental and economic benefits to the cities where it is implemented, considering that, in addition to reducing waste management costs, this favorable economic gain due to the cost of the recycled product being less than the natural aggregate. For Duran et al. (2006), C\&DW becomes economically viable when their landfill dumping cost is higher than the cost of transport to the recycling center, and the cost of using the primary aggregate exceeds the cost of the recycled material.

Facing it, the importance of construction and demolition wastes studies raised due to the scarcity of natural materials and environmental concerns (MENEGAKI; DAMIGOS, 2018). The construction and demolition wastes account for 30 to $40 \%$ of the total mass of produced solid urban waste all over the world (JIN et al., 2018). When improperly managed, this waste causes soil, water, and air pollution (MAHPOUR, 2018).

The quantity and the composition of C\&DW can vary between different regions depending on many factors such as economic growth, legislation, public policy, constructor expertise, type of constructions, regional planning, and others (Menegaki \& Damigos, 2018). It estimated that more than 10 billion tonnes of C\&DW was generated over the world in 2017 (WANG et al., 2019).

In 2016, the European Union generated 923,540,000 tonnes of C\&DW (EUTOSTAT, 2017), in the USA, in 2014, approximately 540 million tonnes were generated (28.9 million tonnes during construction and 511.1 million tonnes during demolition activities). Australia and China in 2014 generated 19.5 million tonnes and 1.13 billion tonnes, respectively (Menegaki \& Damigos, 2018). The United Kingdom, in 2012, generated 200 million tonnes of waste, of which $50 \%$ was produced in Construction and Demolition. Blaisi (2019) informs that in Saudi Arabia in 2016 was generated 131,436 tonnes of C\&DW.

According to Miranda et al. (2009), until 2008, the volume of recycled construction wastes in Brazil was in the range of $4.8 \%$ of the total generated. However, according to Paschoalin Filho et al. (2017), it is estimated that in the country, there is a recycling of up to $21 \%$ of the volume of C\&DW. In Malaysia, this percentage reaches 15\%. In countries like South Korea, Singapore, and Germany, the recycling of C\&DW is in the range of $50 \%$ to $75 \%$ of the total generated, in Australia, this percentage is about 48\% (ESA et al., 2017; TAM et al., 2009).

Environmental, social, and economic advantages of C\&DW recycling in the construction sites have been highlighted by the surveys of Arif et al. (2012); Oyedele et al. (2013); Paschoalin Filho et al. (2017) Tam et al. (2009), among others.

In the last decade (2010-2020), the feasibility and efficient management of C\&DW has been widely studied by many research (PASCHOALIN FILHO et al., 2017). Blaisi (2019) concluded that the critical elements for successful management include (i) awareness of waste management (ii) 
waste management regulations and systems (iii) sustainable building technologies and (iv) C\&DW management plans for construction and demolition work.

According to Paschoalin et al. (2017), the waste generated in a construction site can represent a significant environmental liability, if not adequately managed and destined. In this way, the management of Construction and Demolition Wastes has great importance in ensuring their correct management by adopting techniques in line with sustainability practices.

Nagapan et al. (2012) suggest that the most significant factors causing construction and demolition waste generation are errors in the design and execution phase, inadequate construction planning, poorly skilled labor, and inefficient management of building sites.

\section{Materials and methods}

Concrete waste was collected at a C\&DW Recycling Plant located in São Caetano do Sul / SP. For the execution of the laboratory tests, it was necessary to extract specimens from the concrete waste blocks, which would meet the size recommended in the standard ABNT NBR 12025 (2012).

The procedure for extracting the specimens complied with the criteria stipulated by the standard ABNT NBR NM 7680 (2015). A diamond cup saw was used to extract the specimens, with the following cup dimensions: $50 \mathrm{~mm}$ outside diameter $\times 44 \mathrm{~mm}$ inside diameter $\times 116 \mathrm{~mm}$ height. Figure 1 shows the process of the extraction

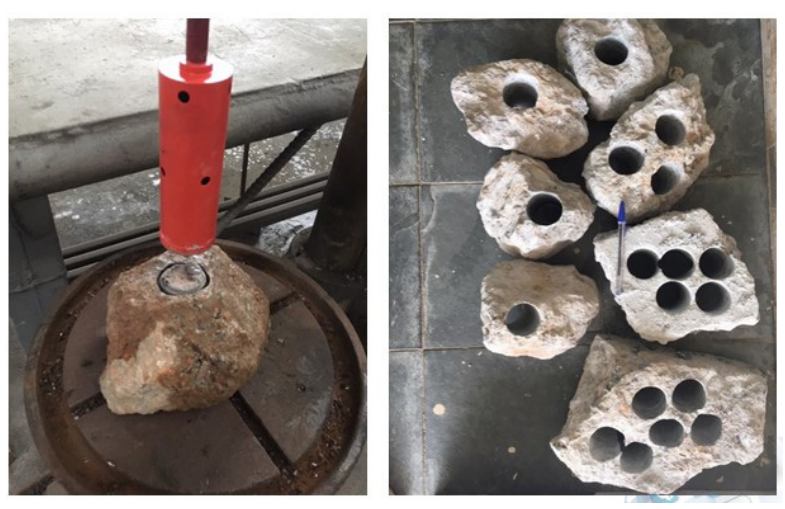

Fig. 1. Extraction of specimens. of the specimen.

A circular Table saw with a 2HP motor, and a 9-inch diamond saw blade was used to homogenize the heights of the extracted specimens, as shown in figure 2. To verify internal fissures existence that could affect the specimen's compressive strength, ultrasound tests were performed according to ABNT NBR 8802 (2010) recommendations. Figure 3 shows an ultrasound test performed for a C\&DW specimen.

Compressive tests were performed to obtain specimen's strength following the procedures given by ABNT NBR NM 8522 (2017). The equipment used was a compression press test equipment, model EMIC GRO48 (300 kN of maximum compressive capacity). Figure 4 and 5 show the specimens prepared for the test and in the process of rupture in the press.

Tests were also performed to determine the Elasticity Modulus of the specimens. This procedure was carried out following the recommendations of ABNT NBR NM 8522 (2017). Figure 6 shows the test in progress.

\section{Results and discussion}

Table 1 presents the physical characteristics of C\&DW specimens. It can be seen that the average diameters obtained for the specimens was 43.84 $\mathrm{mm}$ ( $\mathrm{sd}=0.3 \mathrm{~mm} ; \mathrm{cv}=0.6 \%)$. The average height determined for specimens was $91.54 \mathrm{~mm}$ ( $\mathrm{sd}=$ $1.2 \mathrm{~mm} ; \mathrm{cv}=1.4 \%)$. The average mass obtained was $0.308 \mathrm{~kg}$ ( $\mathrm{sd}=0.01 \mathrm{~kg}, \mathrm{cv}=3.4 \%)$. In terms of average specific weight, the obtained value for C\&DW was $22.35 \mathrm{kN} / \mathrm{m}^{3}$ ( $\mathrm{sd}=0.8 \mathrm{kN} / \mathrm{m}^{3}, \mathrm{cv}=$ $3.4 \%)$.

In general, all construction waste specimens had specific weights according to ABNT NBR 9778, i.e., between 20 and $28 \mathrm{kN} / \mathrm{m}^{3}$. The average specific weight was $22.35 \mathrm{kN} / \mathrm{m}^{3}$, with standard error equal to $0.25 \mathrm{kN} / \mathrm{m}^{3}$.

Therefore, according to the standard deviation value and coefficient of variation determined, it can be assumed that the dimensions of the specimens presented low variations concerning height and 


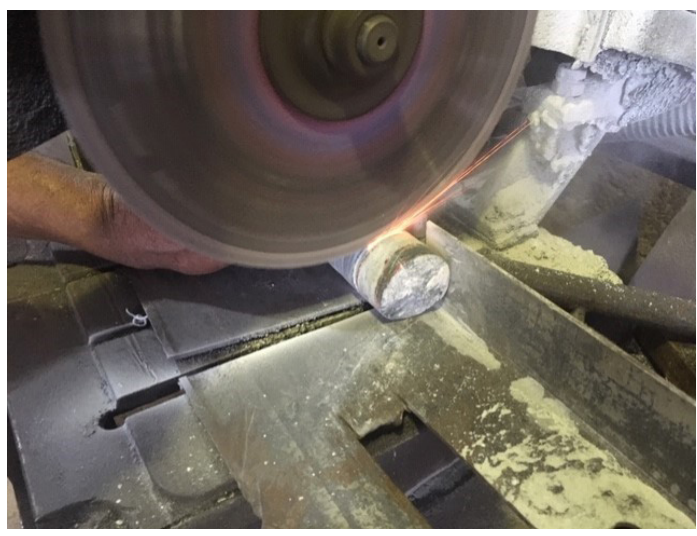

Fig. 2. Homogenization of the heights of the specimens.

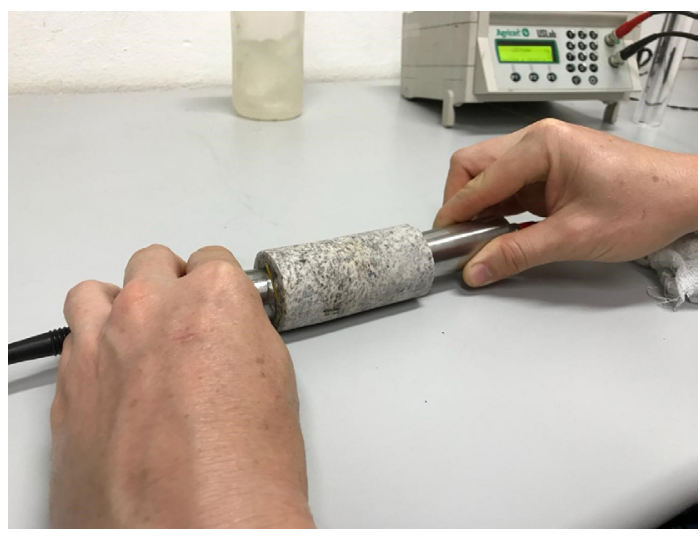

Fig. 3. Ultrasound testing.

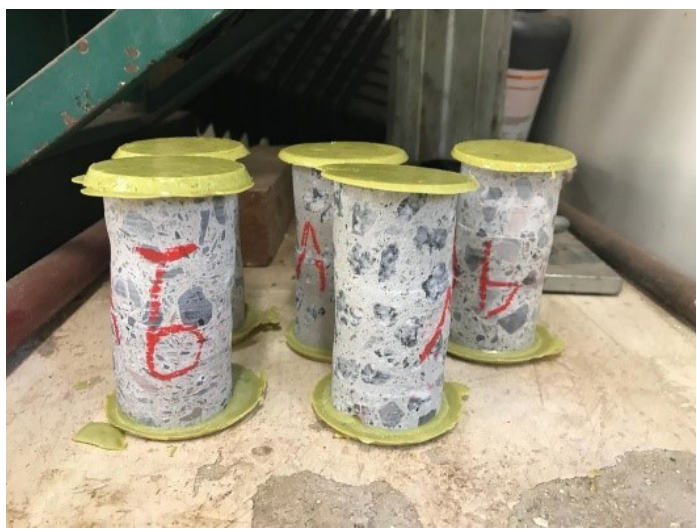

Fig. 4. Capped specimens for compression tests.

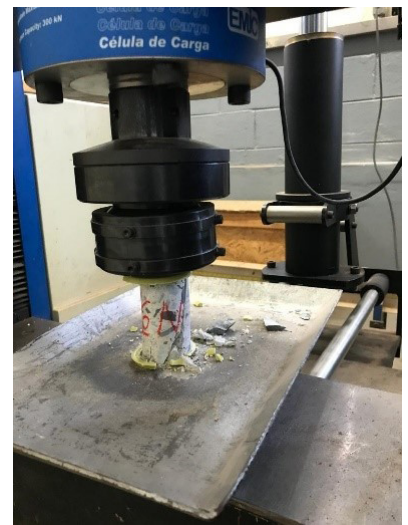

Fig. 5. Rupture of specimens.

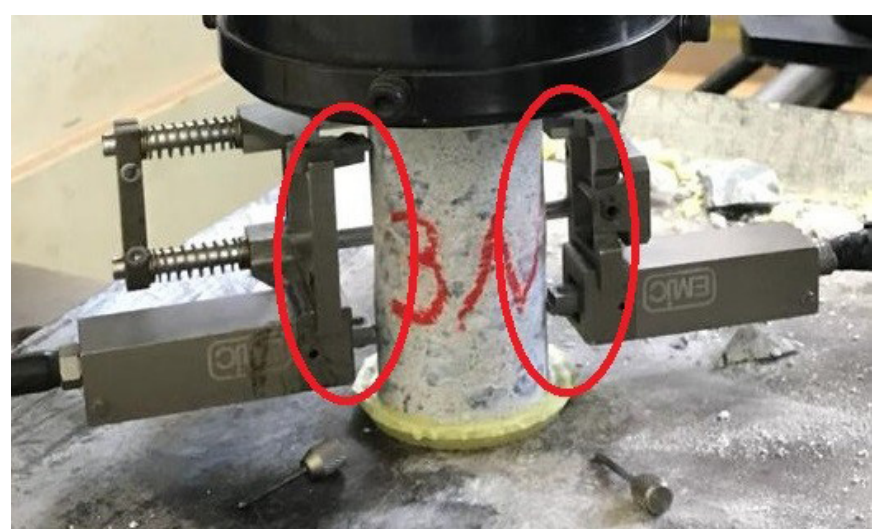

Fig. 6. Modulus of elasticity test.

diameter, which shows that they were satisfactory carved. Besides, the height/diameter ratios are approximately 2.0, which meets the requirements of ABNT NBR 12024 (2010).

Aiming to verify the internal integrity of the specimens, and the presence of micro-cracks and discontinuities that could reduce their compressive strength, ultrasound tests were performed in all specimens before their failure in the compression tests. The values obtained are presented in Table 2.

As shown by Table 2, theaverage wave propagation speed is above $5,000 \mathrm{~m} / \mathrm{s}$, which, according to ABNT NBR NM 8802, indicates the excellent quality of the specimens tested and the absence of pathologies and non-visible heterogeneities that could reduce their compressive strength.

Leal (2012) obtained ultrasonic speed among 6,881 and $11,410 \mathrm{~m} / \mathrm{s}$ for concrete specimens aged 3, 7, 28, and 91 days. According to Naik et al. (2004), apud Leal (2012), the typical wave propagation velocity for good quality concretes ranges from 3,000 to $5,000 \mathrm{~m} / \mathrm{s}$.

According to Table 2, the compressive strength for C\&DW specimens ranged from 11.2 MPa to 32.5 MPa, resulting in an average value of $20 \mathrm{MPa}$, with standard error equal to 1.9 MPa. The average value is lower than determined by Leal (2012), who found an average of $33 \mathrm{MPa}$ for 28-day-old concretes. Martins (2008) performed compressive tests on concrete specimens (28 days aged) and obtained average compressive strengths among 28.8 and $49.1 \mathrm{MPa}$.

Figure 7 shows the correlation obtained between the ultrasound propagation velocity 
Table 1. Physical characterization of C\&DW specimens.

\begin{tabular}{ccccccc}
\hline Specimen & Diameter $(\mathbf{m m})$ & $\begin{array}{c}\text { Cross section } \\
\text { area }\left(\mathbf{m m}^{2}\right)\end{array}$ & Height $(\mathbf{m m})$ & Volume $\left(\mathbf{c m}^{3}\right)$ & Weight $(\mathbf{k N})$ & $\begin{array}{c}\text { Specific weight } \\
\left(\mathbf{k N} / \mathbf{m}^{3}\right)\end{array}$ \\
\hline CDW1 & 43.86 & 1510.1 & 89.28 & 134.8 & 0.299 & 22.18 \\
CDW2 & 43.60 & 1492.3 & 91.48 & 136.5 & 0.309 & 22.64 \\
CDW3 & 43.50 & 1485.4 & 91.22 & 135.5 & 0.300 & 22.14 \\
CDW4 & 43.82 & 1507.6 & 93.14 & 140.4 & 0.312 & 22.22 \\
CDW5 & 43.89 & 1512.2 & 92.22 & 139.5 & 0.325 & 23.31 \\
CDW6 & 44.00 & 1519.8 & 91.16 & 138.5 & 0.305 & 22.02 \\
CDW7 & 44.18 & 1532.2 & 91.77 & 140.6 & 0.307 & 21.83 \\
CDW8 & 44.26 & 1537.8 & 90.09 & 138.5 & 0.294 & 21.22 \\
CDW9 & 43.55 & 1488.8 & 91.65 & 136.5 & 0.326 & 23.89 \\
CDW10 & 43.83 & 1508.0 & 93.35 & 140.8 & 0.310 & 22.02 \\
Average & 43.85 & 1509.4 & 91.54 & 138.2 & 0.309 & 22.35 \\
$\begin{array}{c}\text { Standard } \\
\text { deviation (sd) }\end{array}$ & 0.30 & 0.000017 & 1.2 & 0.0 & 0.00 & 0.80 \\
$\begin{array}{c}\text { Coefficient of } \\
\text { variation - cv (\%) }\end{array}$ & 0.6 & 1.2 & 1.4 & 1.6 & 3.4 & 3.4 \\
\hline
\end{tabular}

and the compressive strength determined by the tests. A linear relationship $\left(R^{2}=0.81\right)$ between the compressive strength and the ultrasound velocity was obtained, demonstrating that the test specimens did not have micro-cracks or internal discontinuities that could influence the test results.

Specimens presentedn an average initial tangent elasticity modulus $\left(\mathrm{E}_{\mathrm{ci}}\right.$ ) equal to $21.2 \mathrm{GPa}$ ( $\mathrm{sd}=$ $7.7 \mathrm{GPa}, \mathrm{cv}=36.3 \%$ ). The average Initial Tangent Elasticity Modulus obtained for C\&DW is within a normal range for typical concretes. Melo Neto and

Table 2. Ultrasound propagation velocity and compressive strength of C\&DW specimens.

\begin{tabular}{ccc}
\hline Specimen & $\begin{array}{c}\text { Ultrasound } \\
\text { velocity }(\mathrm{m} / \mathrm{s})\end{array}$ & $\begin{array}{c}\text { Compressive } \\
\text { strength }(\mathrm{MPa})\end{array}$ \\
\hline CDW1 & $5,160.7$ & 17.60 \\
CDW2 & $5,197.7$ & 15.21 \\
CDW3 & $5,183.0$ & 18.22 \\
CDW4 & $5,511.2$ & 19.51 \\
CDW5 & $6,731.4$ & 26.83 \\
CDW6 & $5,627.2$ & 23.18 \\
CDW7 & $5,126.8$ & 16.38 \\
CDW8 & $5,207.5$ & 11.22 \\
CDW9 & $6,739.0$ & 32.46 \\
CDW10 & $5,692.1$ & 19.47 \\
Average & $5,617.7$ & 20.00 \\
Standard deviation & 623.4 & 6.10 \\
(sd) & & 30.5 \\
Coefficient of & 11.1 & \\
variation (\%) & & \\
\hline
\end{tabular}

Helene (2002) determined that $\mathrm{E}_{\mathrm{ci} 28}$ for different concrete dosages obtain values between 16.4 and 29.0 GPa. Leal (2012) found for concrete CA2O an $\mathrm{E}_{\mathrm{ci}}$ among 30.6 and $33.6 \mathrm{GPa}$. According to the authors, aging and weathering are the main responsible for concrete elasticity modulus reduction.

According to ABNT NBR 6118 (2014), the Initial Tangent Elasticity Modulus for concrete when tests are not available can be estimated using equation 1.

$$
E_{c i}=5600 \cdot\left(f_{c k}\right)^{1 / 2}
$$

Through the results of the C\&DW specimens in the broken natural state and knowing that they are adherent to a standard distribution curve, it is possible to determine through the results of the compression tests the characteristic fck of the waste concrete employing equations 2 and 3 :

$$
\begin{aligned}
& f_{c k}=f_{c j}-1.65 . s \\
& s=\left(\Sigma\left(f_{c c i}-f_{c j}\right)^{2} /(n-1)\right)^{1 / 2}
\end{aligned}
$$

Where:

$\mathrm{f}_{\mathrm{ci}}=$ value obtained in each test;

$\mathrm{f}_{\mathrm{cm}}=$ average value of strength;

$\mathrm{n}=$ number of tests. 


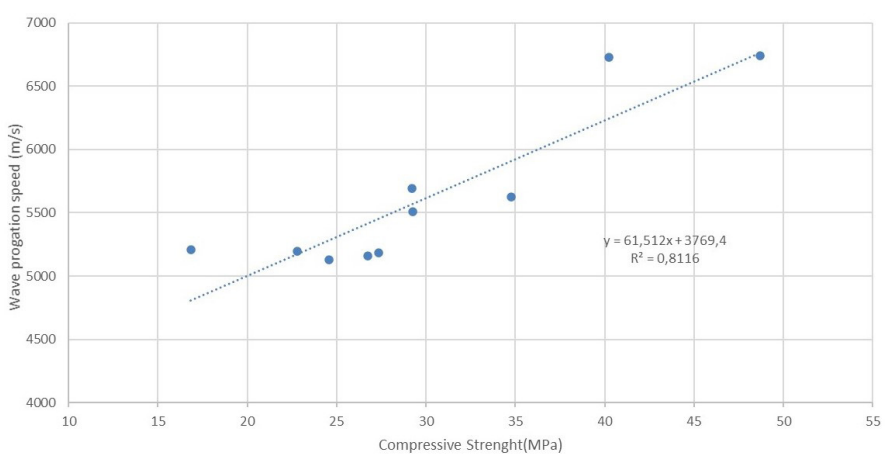

Fig. 7. Correlation between compressive strength and ultrasound velocity.

Considering the results obtained in the compression tests, $\mathrm{s}=4.38 \mathrm{MPa}$ and $\mathrm{f}_{\mathrm{ck}}=11 \mathrm{MPa}$. Therefore, $\mathrm{E}_{\mathrm{ci}}=18.6 \mathrm{GPa}$. According to equation from Martins (2008), $\mathrm{E}_{\mathrm{ci}}=20.0 \mathrm{GPa}$. According to Nunes (2005), $E_{c i}=20.0 \mathrm{GPa}$. According to Molin and Monteiro (1996), $\mathrm{E}_{\mathrm{ci}}=20.1 \mathrm{GPa}$. Then:

$E_{c i, a v e r a g e} / E_{c i}$ ABNT NBR $6118=21.2 / 18.6=1.14$

$\mathrm{E}_{\mathrm{ci} \text {,average }} / \mathrm{E}_{\mathrm{ci}}$ Martins $(2008)=21.2 / 19.9=1.06$

$E_{c i, a v e r a g e} / E_{c i}$ Nunes $(2005)=21.2 / 20=1.06$

$E_{c i \text { average }} / E_{c i}$ Molin and Monteiro (1996) $=21.2 / 20.12$ $=1.05$

Thus, through the values demonstrated, it can be assumed that the equations used to estimate the value of the Initial Tangent Elasticity Modulus allowed values close to the average value obtained for the wastes.

Absorption parameters were also obtained; the obtained data are presented in Table 3. The average absorption for C\&DW specimens was $5.0 \%$ ( $\mathrm{sd}=4.51 \%$ and $\mathrm{cv}=0.32 \%$ ), with values ranging from $3.99 \%$ to $5.08 \%$. According to Leal (2012), absorption is not proper for concrete quality characterization. However, according to the author, good quality concretes commonly presents absorption below $10 \%$. The same author performed absorption tests on concrete specimens CA2O, CA30, and CA40 aged 28 days; values ranging from 5.27 to $6.8 \%$ were determined.
Table 3. Ultrasound propagation velocity and compressive strength of C\&DW specimens.

\begin{tabular}{cc}
\hline Specimen & Water absorption (\%) \\
\hline CDW11 & 4.61 \\
CDW12 & 4.45 \\
CDW13 & 4.56 \\
CDW14 & 3.99 \\
CDW15 & 4.61 \\
CDW16 & 4.44 \\
CDW17 & 4.67 \\
CDW18 & 4.13 \\
CDW19 & 5.08 \\
CDW20 & 4.13 \\
Average & 5.00 \\
Standard deviation (sd) & 4.51 \\
Coefficient of variation (\%) & 0.32 \\
\hline
\end{tabular}

\section{Conclusions}

Through the results obtained, it is possible to state that the recycled C\&DW in its natural state had a specific weight of $22.35 \mathrm{kN} / \mathrm{m}^{3}$; its compressive strength was $30.1 \mathrm{MPa}$. The Initial Tangent Elasticity Modulus was $21.2 \mathrm{GPa}$, where the C\&DW is within a reasonable range of concrete. It is worth noting that the average wave speed obtained employing the ultrasound test for this analyzed set was 5,617.70 m/s, where, according to ABNT NBR 8802 , it indicates the excellent quality of the tested specimens and the absence of pathologies and non-visible heterogeneities that could influence the proposed tests.

The C\&DW used consists of a new alternative to one of the biggest problems faced by civil construction: the destination of the waste generated in the works. Thus, the use of C\&DW for civil construction can create and stimulate higher demand for recycled materials in the C\&DW Recycling Plants.

\section{References}

ASSOCIAÇÃO BRASILEIRA DE NORMAS TÉCNICAS. ABNT NBR NM 8522: Concrete - Determination of static modulus of elasticity and deformation by compression. Rio de Janeiro, ABNT, 2017. 
ABNT NBR NM 7680: Concrete - Sampling, preparing, testing, and result from the analysis of concrete cores Part 1: Axial compressive strength. Rio de Janeiro: ABNT, 2015.

ASSOCIAÇÃO BRASILEIRA DE NORMAS TÉCNICAS. ABNT NBR NM 8802: Hardened concrete Determination of ultrasonic wave transmission velocity. Rio de Janeiro: ABNT, 2010.

ASSOCIAÇÃO BRASILEIRA DE NORMAS TÉCNICAS.

ABNT NBR 9778: Hardened mortar and concrete - Determination of absorption, voids, and specific gravity. Rio de Janeiro, ABNT, 2009.

ARIF, M. et al. Construction waste management in India: an exploratory study. Construction Innovation, v. 12, n. 2, p. 133-155, 2012.

BLSAISI, N. I. Construction and demolition waste management in Saudi Arabia: current practice and roadmap for sustainable management. Journal of Cleaner Production, v. 221, p. 167-175, 2019.

CHEN, J.; HUA, C.; LIU, C. Considerations for better construction and demolition waste management: identifying contractors and government departments' decision-making behaviors through a game theory decision-making model. Journal of Cleaner Production, v. 212, p. 190-199, 2019.

DURAN, X.; LENINGHAN, H.; O'REGAN, B. A model for assessing the economic viability of construction and demolition waste recycling-the case of Ireland. Resources, Conservation, and Recycling, v. 46, n. 3, p. 302-320, 2006.

Eurostat (2017) Report: General and Regional Statistics. Available at: https://ec.europa.eu/ eurostat/publications/all-publications (Accessed July 10, 2019).

ESA, M. R.; HALOG, A.; RIGAMONTI, L. Developing strategies for managing construction and demolition wastes in Malaysia based on the concept of a circular economy. Journal of Material Cycles and Waste Management, v. 19, n. 3, p. 1144-1154, 2017.
Brazilian Institute of Geography and Statistics (IBGE) (2017). Statistical Series \& Historical Series. Retrieved March 24, 2018, from https:// seriesestatisticas.ibge.gov.br/

JIN, R.; YUAN, H.; CHEN, Q. Science mapping approach to assisting the review of construction and demolition waste management research published between 2009 and 2018. Resources, Conservation \& Recycling, v. 140, p. 175-188, 2018.

LEAL, W. R. S. Concrete dosed in a plant: proposal of quality control methodology and identification of the causes of variability in the concrete production process. Dissertation (Master Degree) - Federal University of Santa Catarina. 215p. 2012.

MAIA, A. T.; NETO, A. I. What are the main organizational characteristics of companies in the different segments of civil construction? Revista Ambiente Construído, v. 16, n. 3, p. 197-215, 2016.

MAHPOUR, A. Prioritizing barriers to adopt a circular economy in construction and demolition waste management. Resources \& Recycling, v. 134, p. 216-227, 2018.

MelO Neto, A. A.; Helene, P. Elasticity Module: Dosing and Evaluation of Concrete Elasticity Modulus Prediction Models. In: 44th Brazilian Concrete Congress, Belo Horizonte, 17-22 august 2002.

MENEGAKI, M.; DAMIGOS, D. A review on current situation and challenges of construction and demolition waste management. Current Opinion in Green and Sustainable Chemistry, v. 13, p. 8-15, 2018.

MIRANDA, L. F. R.; ANGULO, S. C.; CARELI, E. D. The recycling of construction and demolition waste in Brazill: 1986-2008. Constructed Environment, v. 9 n. 1, p. 57-71, 2009.

NAGAPAN, S.; RAHMAN, I. A.; ASMI, A. Factors Contributing to Physical and Non-Physical Waste Generation in the Construction Industry. International Journal of Advances in Applied 
Sciences, v. 1, n. 1, p. 1-10, 2012

OYEDELE, L. O. et al. Reducing waste to landfill in the UK: identifying impediments and critical solutions. World Journal of Science, Technology, and Sustainable Development, v. 10, n. 2, p. 131142, 2013.

PASCHOALIN FILHO, J. A. et al. Construction Waste Management in High Standard Residential Buildings in the Municipality of São Paulo/SP. Journal of Social and Environmental Management, v. 11, n. 1, p. 73-89, 2017.

YUAN, H. A model for evaluating the social performance of construction waste management. Waste Management, v. 32, n. 6, p. 1218-1228, 2012.

TAM, W. Y. V.; KOTHAYOTHAR, D.; LOO, Y. C. On the prevailing construction waste recycling practices: a South East Queensland study. Waste Management \& Research, v. 27, n. 2, p. 167-174, 2009.

WANG, J. et al. Considering life-cycle environmental impacts and society's willingness to optimize construction and demolition waste management fee: An empirical study of China. Journal of Cleaner Production, v. 206, p. 1004-1014, 2019. 